\title{
INDIFFERENTE EN LABIELE EVENWICHTEN IN ECONOMISCHE STELSELS.
}

\author{
Door Prof. Dr. J. TinBERGEN.
}

1. Drie soorten evenwicht. -2 . Gemengde evenwichten. - 3. Kritiek op de gangbare opvatting. - 4. Wanneer is de prijs een goede regulateur? - 5 . Voorbeelden van bijna indifferente evenwichten. A. de tarwemarkt. - 6. B. Het verband tussen productie en inkomen. 7. C. De arbeidsmarkt. $-8 \mathrm{D}$. Het wisselkoersmechanisme.

\section{Drie soorten evenwicht.}

Enige jaren geleden is door Prof. Goudriaan in dit tijdschrift de belangrijke vraag van de aard der economische evenwichten aangesneden ${ }^{1}$ ). En ofschoon de economische wetenschap zich in enkele gevallen met deze materie heeft beziggehouden, kan men toch niet anders doen dan Goudriaan bijvallen, wanneer hij wijst op de vele onontgonnen gebieden die de economie hier vertoont. Daar het hierbij gaat om een in laatste instantie quantitatieve kwestie, behoeft deze achterstand geen verbazing te wekken: er is in 't algemeen een achterstand in de quantitatieve behandeling van economische vraagstukken. In het volgende willen wij trachten een verdere bijdrage te leveren tot het begrip van deze zaken.

Ofschoon analogieën met andere wetenschappen gewoonlijk gevaarlijk zijn — ,elke vergelijking gaat mank”-, is ter inleiding een herinnering aan de drie soorten evenwicht die de natuurkunde kent wel geschikt. Men onderscheidt daar immers stabiele, labiele en indifferente evenwichten. Een knikker in het diepste punt van een schaal bevindt zich in stabiel evenwicht, een knikker op een heuveltop in labiel en een knikker op een plat vlak in indifferent evenwicht. Het criterium is gelegen in de bewegingen die de knikker uitvoert, wanneer hij door welke oorzaak ook (een "toevallige"

1) Prof. Dr. Ir. J. Goudriaan Jr.: „Eerste Hulp", De Economist 80 (1931), blz. 876.

Econ. 1941 . 
oorzaak) een klein eindje verwijderd geraakt van de evenwichtsstand. Voert deze beweging hem terug naar de oorspronkelijke stand, dan is er stabiel evenwicht; voert $z \mathrm{ij}$ hem steeds verder van deze oorspronkelijke stand af, dan is er labiel evenwicht; en treedt geen beweging in, d.w.z. blijkt de nieuwe stand ook een evenwicht te $z$ ijn, dan spreken wij van indifferent evenwicht.

Deze dingen zijn bekend genoeg. $Z$ ij bieden ons, bij zorgvuldige overbrenging in de economische sfeer, echter gezichtspunten, in die sfeer nog niet algemeen bekend of aanvaard.

Het prototype van een evenwicht - waartoe zich de meeste, zo niet alle evenwichten laten herleiden - wordt in de economie gegeven door het evenwicht van één markt, beschreven door vraag- en aanbodcurve. Als regel is de vraagcurve naar rechts dalend, de aanbodcurve naar rechts stijgend. Men pleegt het door twee zodanig verlopende curven gevormde evenwicht in de economiemie als stabiel te beschouwen. De redenering is deze: als de prijs eens even zou afwijken van die behorende bij het snijpunt, dan zou dat betekenen:

(a) bij een lagere prijs: meer vraag, minder aanbod, dus prijsstijging;

(b) bij een hogere prijs: minder vraag, meer aanbod, dus prijsdaling.

Er is, als deze deducties juist zijn - wij komen daarop nog even terug, doch in 't algemeen zijn zij aanvaardbaar - een beweging naar het evenwicht toe en dus stabiel evenwicht.

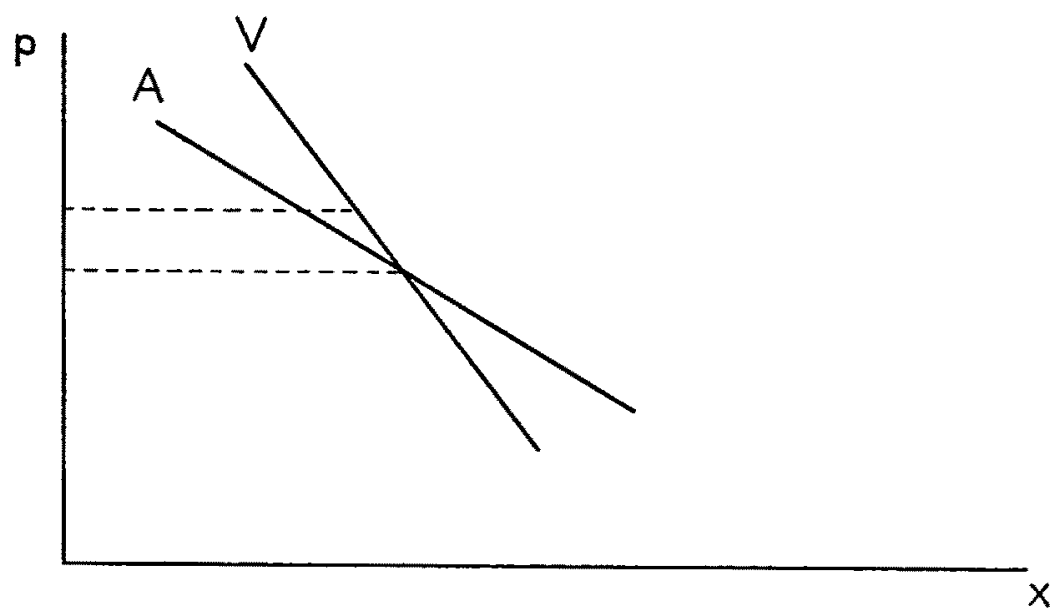

Fig. 1. 
Zouden de vraag- en aanbodcurve anders lopen, dan behoeft dat niet het geval te zijn. Het gaat hierbij overigens alleen maar om de kwestie of, bij hogere prijzen dan in 't evenwicht, er een overwicht van aanbod boven vraag ontstaat of niet. Als er een overwicht van vraag boven aanbod ontstaat, is er een verdere prijsverhoging te verwachten. Dit doet zich o.m. voor, wanneer de aanbodcurve naar rechts daalt en wel minder steil verloopt dan de vraagcurve (zie fig. 1). Voor het moment stellen wij dit geval geheel en al theoretisch, zonder te willen zeggen, dat het zich bij een kleine afzonderlijke markt zal voordoen. In het vervolg van ons betoog zal echter blijken, dat het geval zich zeer goed kan voordoen, indien men rekening houdt met de wijzigingen die de prijs van die markt via de inkomensvorming uitoefent op de overige aanbodcondities. Daartoe moet die markt dan een zeer groot deel van alle in de volkshuishouding plaats vindende transacties omvatten; ons voorbeeld heeft betrekking op de wisselkoersmarkt (zie $\$ 8$ ). Een bij zodanige loop van vraag- en aanbodlijn optredende prijsstijging betekent een verdere verwijdering van het evenwicht; gewoonlijk zal in een dergelijk geval bij een lagere prijs dan de evenwichtsprijs ook een verdere prijsdaling optreden. Er is dan dus sprake van een labiel evenwicht.

Een tussengeval is dat waarbij vraag- en aanbodcurve samenvallen. Als dan de prijs zich - door een toevallige oorzaak van zijn aanvankelijke evenwichtsstand verwijdert, zal hij daar ter plaatse opnieuw in evenwicht zijn. Er is nu indifferent evenwicht.

\section{Gemengde evenwichten.}

Ook deze economische voorbeelden zijn niet nieuw. $Z$ ij hebben een plaats gevonden in verschillende bekende leerboeken. Niet lang geleden heeft de bekende Engelse econoom $N$. Kaldor aan deze begrippen nog toegevoegd het begrip der gemengde evenwichten ${ }^{2}$ ). Wanneer nl. de vraag- en aanbodcurve elkaar niet snijden, doch aan elkaar raken, dan doet zich het belangwekkende feit voor, dat het evenwicht naar de ene richting stabiel en naar de andere labiel kan zijn. Dit betekent dat een toevallige afwijking naar de ene kant een spoedige terugkeer naar het uitgangspunt ten gevolge heeft, doch een toevallige afwijking naar de andere

2) N. Kaldor, A Model of the Trade Cycle, Economic Journal, L (1940), p. 79 . 
kant een sterke verwijdering. Kaldor beschouwt in het bijzonder de situaties in de hoogtepunten en dieptepunten van de conjunctuur op de markt der kapitaaldispositie als dergelijke' gemengde evenwichten en heeft daarmee een zeer belangrijke bijdrage geleverd tot de verklaring van het bekende asymmetrische karakter van de conjunctuurbeweging. In de hoogconjunctuur zou dan de situatie zodanig zijn, dat een kleine gunstige afwijking weinig verandering tot gevolg heeft, doch een kleine ongunstige verandering een grote daling van de activiteit. Men zou de tegenwerping kunnen maken, dat het wel heel erg toevallig is, wanneer de twee curven aan elkaar raken. Kaldor ziet dit echter aldus, dat als gevolg van een voortdurende verschuiving van de curven t.o.v. elkaar er - bij een bepaalde vorm dezer krommen - op het een of andere tijdstip een situatie van raking kan ontstaan. Wanneer precies, dat kan hij ook niet zeggen; en door deze onbepaaldheid in het tijdstip van het optreden te erkennen, maakt hij het feit van het optreden van het verschijnsel minder onwaarschijnlijk.

\section{Kritiek op de gangbare opvatting.}

Alvorens tot het hoofdpunt van ons verdere betoog te komen, willen wij nog wijzen op één punt van theoretische aard. Vaak wordt gemeend dat de kennis van de stand van vraag- en aanbodcurve voldoende is, om uit te maken of een evenwicht stabie! dan wel labiel is. Ons voorbeeld hierboven volgt die gebruikelijke betoogtrant. Geheel juist komt deze ons echter niet voor. Eigenlijk moet men behalve de vraag- en aanbodcurve, die ik als tijdloze begrippen statisch wil noemen, ook nog iets weten (evt. veronderstellen) omtrent het gedrag van de markt in de tijd (het dynamisch karakter). En in afhankelijkheid van dit dynamisch karakter kan bij dezelfde stand van vraag-en aanbodcurve de ene maal cen stabiel, de andere maal cen labiel evenwicht optreden. Dit willen wij eerst aan een zeer eenvoudig voorbeeld toelichten. Wij kiezen daartoe het bekende spinnewebtheorema (cob web theorem), dat, zoals men weet, de situatie vrij goed benadert die er heerst op de varkensmarkt en de koffiemarkt en eveneens bij een aantal akkerbouwproducten, zolang de opbrengsten per ha toevallig weinig fluctuaties vertonen. In fig. 2 zijn van een bepaalde markt een vraag- en een aanbodcurve getekend. Wij nemen nu aan dat 
deze markt zich in de tijd aldus gedraagt dat een hogere prijs onmiddellijk de vraag doet dalen overeenkomstig de vraaglijn, terwijl het aanbod eerst na een zekere vertragingstijd („lag”) reageert.Bij de zoëven genoemde varkensmarkt is deze vertraging

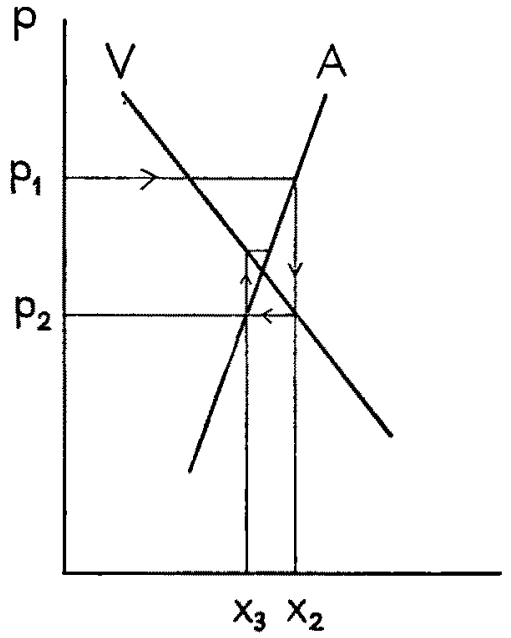

Fig. 2A.

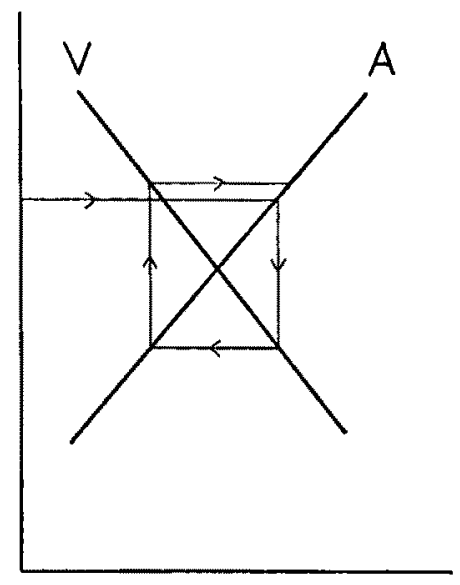

Fig. 2B.

ongeveer $11 / 2$, bij de koffiemarkt 7 en bij akkerbouwproducten 1 jaar. Wij nemen deze "lag" als tijdseenheid aan. Als nu op tijdstip 1 een prijs $p_{1}$ ontstaat door een toevallige oorzaak, dan zal deze eerst op tijdstip 2 leiden tot een verhoogd aanbod $x_{2}$. Wil dit aanbod worden opgenomen, dan kan dat - omdat de vraag onmiddellijk reageert - indien slechts de prijs zich instelt op $p_{2}$. De aanbodshoeveelheid $x_{3}$ zal met $p_{2}$ functioneel verbonden zijn volgens de aanbodlijn en in de periode 3 voeren tot een prijs $p_{3}$. Enzovoort. De ontwikkeling van de grootheden $p$ en $x$ wordt door de spinneweb-achtige figuur van fig. $2^{\mathrm{A}}$ weergegeven. Er treedt in dat geval een schommeling op die op den duur terugvoert tot het evenwicht. Dit laatste is dus stabiel.

Men zou kunnen menen, dat dit resultaat in overeenstemming is met het in $\S 1$ vermelde. Een blik op fig. $2^{B}$ doet echter zien, dat het thans verkregen resultaat niet steeds zal optreden wanneer de aanbodcurve een positieve en de vraagcurve een negatieve helling vertoont, zoals bij de vorige redenering wel het geval was. Het blijkt dat bij het cob-web theorema zich ook een niet-stabiel evenwicht kan voordoen. Zodra de helling van een der curven 
zodanig gewijzigd wordt, dat de aanbodcurve minder steil verloopt dan de vraagcurve (d.w.z. de aanbodselasticiteit groter is dan de vraagelasticiteit), komen de punten niet steeds dichter bij het evenwicht, doch verwijderen zich daarvan. We krijgen hier dus geen stabiel evenwicht, doch een van een nog niet besproken soort: er worden steeds heviger wordende schommelingen om de evenwichtsstand volbracht. Bij het natuurkundig voorbeeld van de knikker deed zich dit geval niet voor; er is echter alle reden om ook hier van een labiel evenwicht te spreken ${ }^{3}$ ).

Nu blijkt bij nadere beschouwing, dat het dynamisch gedrag van de markt bij het spinnewebtheorema anders wordt aangenomen dan bij de gangbare redenering. $\mathrm{Bij}$ deze laatste worden vraag en aanbod symmetrisch behandeld, bij het spinnewebtheorema niet. Overigens is de gang van zaken bij het cob-web theorema nauwkeurig beschreven, bij de gangbare redenering niet. Het wordt daar in het midden gelaten, hoe de nadering tot de evenwichtsstand geschiedt. Dat kan b.v. aldus zijn, dat een overschot van aanbod boven vraag tot voorraadvergroting leidt en de voorraad een tegengestelde invloed op de prijs uitoefent. Hoe sterk deze laatste invloed is en hoeveel tijd ermede gemoeid is wordt niet vermeld en doet ook blijkbaar niet ter zake. Niettemin impliceert toch reeds de symmetrische behandelingswijze een hypothese omtrent het dynamisch gedrag van de markt.

3) Men spreekt hier ook wel eens van een explosief geval, doch dat is slechts bij wijze van spreken. Het is n.l. niet zeker dat de afwijkingen van het evenwicht die achtereenvolgens optreden, steeds groter zullen worden. Wanneer zij zo groot zijn geworden, dat men buiten het geldigheidsgebied van de als benadering aangenomen vraag- en aanbodcurven komt, kan het ook zijn dat aan die vergroting een eind komt. Gewoonlijk zullen zich na enige tijd ook in het vraag- en aanbodschema niet opgenomen verschijnselen gaan voordoen, waardoor de aard van het vraagstuk een andere wordt: van economisch kan het tot sociaal vraagstuk worden, enz.

Er moge in dit verband nog even op gewezen worden dat dus een beweging waarbij de amplitude der schommelingen constant blijft een tussenvorm is tussen stabiele en labiele evenwichten, waarvoor de naam indifferent evenwicht niet op zijn plaats is. Het gaat hier om een soort evenwicht dat in de natuurkunde slechts als grensgeval optreedt.

Tenslotte zij er op gewezen, dat zich ook in de economie gevallen kunnen voordoen, analoog met dat van een knikker in een schaal waarin zich kleinere of grotere ,heuvels" voordoen; er zijn dan, op enige afstand van elkaar, meer evenwichten, waarvan sommige stabiel, andere labiel zijn. Men vgl. mijn artikel „Ueber den Wert mathematischer Konjunkturtheorien" in de Beiträge zur Konjunkturforschung, Hamburg 1936. 


\section{Wanneer is de prijs een goede regulateur?}

Wij willen ons echter in hetgeen volgt t.a. v. deze dynamische karaktertrekken der te beschouwen stelsels op het gangbare standpunt plaatsen. Wij keren terug tot de drie mogelijkheden t.a.v. de relatieve stand van vraag- en aànbodcurve, in de aanvang beschouwd. Deze relatieve stand kan ons nl. ook iets leren omtrent de verplaatsing van de evenwichtsstand bij het verschuiven van een der curven of van beide curven. Heeft men, bij een stabiel evenwicht in de gangbare betekenis, een vraag- en aanbodcurve die duidelijk van richting verschillen, dan zal een kleine ,shift" in een der lijnen een slechts kleine verplaatsing van het evenwicht ten gevolge hebben. Of andersom geformuleerd: een kleine prijsverandering is dan voldoende om een door een kleine shift veroorzaakte evenwichtsverstoring te verhelpen. Dit zijn de gevallen, waarin de prijs ,een goede regulateur" kan zijn.

Denken wij ons als tegenstelling nu het geval, waarbij vraagen aanbodlijn ongeveer parallel verlopen. Een kleine verschuiving zal hier ten gevolge hebben, dat een aanzienlijke wijziging in de evenwichtsstand optreedt. Of, ook weer andersom gezegd: om de door een kleine "shift" veroorzaakte evenwichtsverstoring te compenseren is nu een belangrijke prijsverandering nodig. De prijs is in deze gevallen een ondoelmatige regulateur. Beter is in dergelijke gevallen de regulatie ook door een (tegengestelde) "shift" te doen plaats hebben. Daarbij kan dan de prijs eenvoudigheidshalve beter gefixeerd blijven.

De nadere studie der evenwichten kan ons dus een middel aan de hand doen om te onderscheiden in welke gevallen de prijs als regulateur wel, in welke gevallen hij niet kan voldoen. Hiertoe is dan echter voor alles nodig de kennis der quantitatieve verhoudingen op de markten waarom het gaat; in laatste instantie dus meting. Het is niet de bedoeling van dit artikel om de details van metingen aan de lezers voor te leggen. Doch wel willen wij een aantal gevallen beschouwen, waarin een voorlopige verkenning tot het vermoeden voert dat men te doen heeft met bijna indifferente evenwichten, met de consequenties daarvan. Daarbij zullen wij ons niet uitsluitend, zelfs niet voornamelijk bezighouden met afzonderlijke markten, zoals tot hier toe in onze theoretische beschouwingen. Zoals blijken zal, liggen de belangrijkste voorbeelden daar waar men gehele complexen van markten beziet. 
5. Voorbeelden van bijna indifferente evenwichten. A. De tarwemarkt.

Toch beginnen wij onze voorbeelden met een geval dat wel betrekking heeft op een afzonderlijke markt, om de lezer de overgang te vergemakkelijken. Dit eerste voorbeeld heeft betrekking op de tarwemarkt. Men heeft daar te doen met een artikel, waarvan zowel de vraag als het aanbod zeer weinig elastisch zijn. Zowel de vraag- als de aanbodlijn zijn dus bijna verticaal. Een kleine verschuiving van een van beide kan tot gevolg hebben dat een sterk verschillende prijs nodig is om het evenwicht te herstellen. Deze markt moet dus wel zeer sterke prijsschommelingen te zien geven, en de prijs is er geen zeer goede regulateur. Op een en ander is in het bijzonder gewezen door Dr. Ir. Dijt, die er zijn betoog ten gunste van goederenschappen op gebaseerd heeft ${ }^{4}$ ).

\section{Voorbeeld $B$. Het verband tussen productie en inkomen.}

Het tweede voorbeeld waarvoor ik de aandacht wil vragen heeft niet betrekking op de prijsvorming in engere $z$ in, doch wel op een economisch evenwicht en wel een zeer belangrijk. Het gaat om het door Keynes en de zijnen zo in het centrum gebrachte verband tussen de waarde van de productie en de inkomens. Denken wij ons voorshands een land zonder betalings- en handelsverkeer met het buitenland - men kan soortgelijke beschouwingen opstellen voor een land met zodanig verkeer - en geven wij de waarde van de gezamenlijke productie aan door $U$, het bedrag der inkomens met $Y$. Er bestaat dan op twee wijzen verband tussen deze twee grootheden.

(1) Daar de inkomens uit de productie voortkomen moet $Y=U$ zijn;

(2) Daar de productie, via de vraag naar goederen, een gevolg is van de besteding der inkomens, moet $U$ met $Y$ samenhangen via de "propensity to consume":

$$
U=f(Y)
$$

waarbij deze overigens zo ruim moet worden opgevat, dat onder „Consumeren" ook valt investeren; men zou dus misschien beter

4) Vgl. M. D. Dijt, Conjunctuurbeheersching door goederenschappen, Proefschrift Wageningen, Amsterdam 1933. 
kunnen spreken van de neiging tot uitgeven (propensity to spend). Voorzover wij statistisch over deze functie zijn ingelicht ${ }^{5}$ ) is wel waarschijnlijk, dat zij weinig zal afwijken van $U=Y$; een lineaire benadering

$$
U=a Y+b
$$

zal dus zodanig zijn, dat $a$ ongeveer $=1$ en $b$ ongeveer gelijk aan 0 is.

De twee relaties tezamen vormen de twee helften - als men het zo wil uitdrukken - van het circulatieproces; en dit proces zal tot een evenwicht leiden, wanneer aan beide door de waarden $U$ en $Y$ voldaan wordt. Dat wil zeggen, dat meetkundig de zaak precies zo kan worden voorgesteld als bij de vraag- en aanbodcurve; het gaat ook nu om een snijpunt van de twee curven (1) en (2).

Blijkens het voorgaande gaat het echter nu om twee curven die elkaar zeer dicht benaderen, zodat kleine verschuivingen van de curven voldoende zijn om het evenwicht sterk te verstoren. Zelfs zou men, voor beschouwingen op zeer lange termijn, kunnen beweren dat in de bestedingsfunctie (2') $a=1$ en $b=0$ is: „op den duur" zal men zijn uitgaven aanpassen aan zijn inkomsten; en dan hebben we blijkbaar het geval van een indifferent evenwicht.

Wij hebben daarmee niets nieuws beweerd, doch hoogstens een oude waarheid in een nieuw kleed gepresenteerd. Ten onzent heeft Goudriaan er in zijn praeadvies-1937 voor de Vereniging voor de Staathuishoudkunde en de Statistiek in het bijzonder op gewezen met de formulering: de totale vraag naar goederen en diensten is onbepaald.

Beschouwt men de samenhang tussen inkomens en waarde der productie nit tijdloos, zoals wij nu net deden, doch houdt men rekening met de tijdsafstanden, dan krijgt men het in een realistischer vorm die aan de beschouwingswijze van Robertson doet denken Men zal dan bij ten minste een der beide hierboven gegeven vergelijkingen met een "lag" rekening houden. Indien wij onder $\dot{Y}$ verstaan het inkomen op het moment van totstandkoming, dan is er geen aanleiding om in de eerste dier vergelijkingen cen "lag" aan te nemen. Deze bliift dus: $Y=U$. Doch in de tweede vergelijking moet dan de $Y$ op een voorafgaand tijdstip worden genomen:

5) In diverse econometrische onderzoekingen van de laatste tijd is aan deze kwestie andacht besteed. Men zie b.v. R. \& W. M. Stone, The marginal propensity to consume and the multiplier, Review of Economic Studies VI (1938-1939), p. 1 en mijn Statistical Testing of Business Cycles, I en II, uitgave Volkenbond. 
de uitgaven zullen afhangen van het - in Robertson's terminologie: beschikbare inkomen, $Y^{\prime}$, dat gelijk kan worden aangenomen aan het inkomen dat in een voorafgaande periode tot stand gekomen is: $Y_{t}^{\prime}=Y_{t-1}$ waarbij de index de tijdruimte voorstelt, waarop de grootheid betrekking heeft. De bestedingsvergelijking wordt dan: $U=a Y_{t-1}+b$

Men kan met de dan verkregen twee vergelijkingen een proces in de tijd beschrijven, b.v. wanneer $a>1$, het bekende cumulatieve proces van de conjunctuurtheorie. Inplaats van de door Goudriaan genoemde onbepaaldheid der grootheden krijgt men dan een beschrijving van het proces der verwijdering dezer grootheden van een oorspronkelijk evenwicht of de nadering tot een nieuw evenwicht (dit laatste voor $a<1$ ). In beide gevallen betekent dat echter de mogelijkheid dat inkomens en waarde der productie zich geruime tijd kunnen bewegen zonder snel terug te keren tot één bepaald evenwicht en dat is vrijwel hetzelfde wat waarschijnlijk ook Goudriaan bedoelde.

\section{Voorbeeld C. De arbeidsmarkt.}

Het derde voorbeeld beweegt zich - evenals het vierde weer op het gebied van de prijsvorming, doch thans niet meer in de veronderstelling dat de vraag- en de aanbodlijn aan shifts zijn onderworpen die van het resultaat der prijsvorming onafhankelijk zijn. Deze veronderstelling wordt gewoonlijk gemaakt bij het presenteren van de vraag- en aanbodschema's à la Marshall en is te aanvaarden voor markten die slechts een klein gedeelte van het gehele economisch leven van een land omvatten. Met name de inkomens, de belangrijkste factor die de stand van de vraagcurve bepaalt, zijn echter weer afhankelijk van de omgezette hoeveelheden en de prijzen van alle markten tezamen. Wil men de prijsvorming van een niet-kleine markt dus op juiste wijze bestuderen, dan moet men deze interdependentie ook in zijn beschouwingen betrekken. En daarbij kan juist ook weer blijken dat vraag- en aanbodlijn, op die wijze vastgesteld, in bijna-evenwijdige stand kunnen verkeren.

Het derde voorbeeld, dat nu eerst nader beschouwd zal worden, heeft betrekking op de loonvorming; gemakshalve in een land zonder verkeer met het buitenland.

Ten aanzien van de aanbodcurve van arbeid valt het volgende op te merken. Uitgaande van het feit dat werklozensteun wordt verstrekt, kan men aannemen dat slechts een klein gedeelte der bevolking bereid is te werken voor een loon, lager dan de steun. Als het loon echter allengs hoger wordt verondersteld, zal het aantal aanbieders snel stijgen, zodat voor een loon dat zeg $25 \%$ boven de steun ligt een groot gedeelte van de bevolking werk- 
kracht aanbiedt. Tot her toe is het aanbod dus elastisch. Als praktisch de gehele bevolking zich eenmaal aanbiedt, begint echter een gebied van inelasticiteit. Ook vrij aanzienlijke loonstijgingen zullen niet tot een groter aanbod van arbeid leiden. Zelfs is het niet uitgesloten dat zich tegenwerkende tendenties voordoen: dat als gevolg van het hoge loon de arbeid van vrouwen en kinderen afneemt. Er zal dus een belangrijk interval van de aanbodcurve zijn, dat vrijwel inelastisch is, d. w. $z$. weergegeven kan worden door een lijn evenwijdig aan de verticale as op een afstand van die as gelijk aan de grootte der voor arbeid in aanmerking komende bevolking. In de periode 1920-1940, die wij meer in het bijzonder in de gedachten hebben, zal aan de genoemde voorwaarden o.i. voldaan zijn geweest. In hoeverre bij een nog verdere stijging der lonen "de voor arbeid in aanmerking komende bevolking" zich nog zal uitbreiden, laten wij in het midden. Als speciaal het loon voor vrouwen en jeugdigen zou stijgen, is het mogelijk dat die categorieën zich meer aanbieden; doch als de lonen der mannen eveneens stijgen, kan men dat, zoals gezegd, betwijfelen.

Het is vooral de vraag, waarom het gaat. Hoe is het verloop van de vraagcurve, d.w.z. hoe hangt de vraag naar arbeid, van de zijde der ondernemers, af van de loonshoogte $l$ ? Bij een gegeven stand van de techniek is er tussen de hoeveelheid arbeid die gevraagd wordt en de hoeveelheid product die vervaardigd wordt een gegeven verband ${ }^{\circ}$ ) en daarom kan men evengoed de vraag stellen: hoe hangt de omvang van de productie af van de loonvoet $l$ ? Om deze vraag te beantwoorden kunnen wij, weer een schrede verder gaand, zeggen dat de omvang van de productie bepaald wordt door de vraag naar en het aanbod van goederen, en wij interesseren ons dan in het bijzonder voor de veranderingen die daarin optreden als gevolg van een loonswijziging. Dit is een kwestie die in de literatuur reeds meermalen uitvoerig is behandeld. Men heeft er de bekende controverse over tussen wat in de wandeling hier te lande heette de aanpassings- en de koopkrachttheorie. Kort gezegd - in ons aanhangsel hopen we verantwoording te geven - komt het hierop neer, dat bij ver-

6) Wij verwaarlozen hier dus de invloed die het loonniveau zou kunnen hebben op de verhouding tussen de hoeveelheden aangewende arbeid en aangewend kapitaal. Deze invloed doet zith eerst op zier lange termijn gevoelen. 
hoging van de loonvoet twee tegengestelde tendenties t.a.v. de omvang van de productie zich voordoen. Aan de ene kant wordt de productie duurder, de prijs dus hoger en de afzet daardoor verminderd. Aan de andere kant wordt echter het looninkomen per werkende arbeider verhoogd en zijn vraag naar goederen daardoor ook. Het hangt dan van een aantal feitelijke gegevens af, welke dezer twee tendenties de sterkste is. $\mathrm{Er}$ is in 't algemeen een grotere waarschijnijkkheid dat bij hogere loonvoet de omvang van de productie lager zal zijn. Maar er zijn economische structuren denkbaar - in 't bijzonder dan, wanneer men met een gesloten land heeft te doen - waarvoor de twee tendenties elkaar precies opheffen - men zie het aanhangsel. En deze structuren liggen geheel binnen de grenzen van het realistische, voorzover we statistisch geïnformeerd zijn. In deze gevallen loopt dus de vraaglijn naar arbeid evenals de aanbodlijn verticaal: ze zijn evenwijdig. Als deze gevallen mogelijk zijn, zijn er dus ook tussengevallen mogelijk, waar de vraaglijn bijna evenwijdig loopt aan de aanbodlijn. Wij hebben dan dus inderdaad een ander voorbeeld van een markt waar de prijs geen geschikt regulator is; waar een gelijkmaking van vraag en aanbod beter door een verschuiving van een der beide curven kan geschieden. En ook al lopen de lijnen niet nauwkeurig evenwijdig aan elkaar, dan toch kan hun snijpunt zo ver verwijderd liggen dat het een volkomen ondenkbare situatie representeert: lang voordat die door ,aanpassing" verkregen zou zijn, zouden geheel andere verschijnselen optreden, die met ontwrichting gelijk zouden staan.

Dit derde voorbeeld onderscheidt zich van de voorafgaande, in het bijzonder van het eerste, daardoor, dat thans een zo omvattend gedeelte van het economisch leven daaronder valt, dat van het eenvoudige vraag- en aanbodschema voor kleine markten niet meer gewerkt kan worden en bepaalde interdependenties daarin verdisconteerd moeten worden.

\section{Voorbeeld D. Het wisselkoersmechanisme.}

Het vierde voorbeeld van een indifferent of bijna indifferent prijsevenwicht willen wij ontlenen aan de theorie der wisselkoersen. Wij gaan dus thans een land beschouwen waarvan het verkeer met het buitenland niet te verwaarlozen, doch integendeel belangrijk is. En wij interesseren ons daarbij in 't bijzonder voor de 
totstandkoming van de wisselkoers. Ook hierbij zullen wij vraagen aanbodlijn en wel van de valuta van dat land, zeggen wij van guldens, moeten beschouwen. Gemakshalve doen wij alsof er alleen lopende posten op de betalingsbalans voorkomen. Voor een statische beschouwingswijze als waarvan wij uitgaan is dit natuurlijk. Dit beteekent dat wij zowel kapitaal- als ook goudbewegingen uitsluiten. Over de consequenties daarvan zal nog worden gesproken. Verder spreken wij alleen van in- en uitvoer en verstaan onder uitvoer niet alleen die van goederen, maar ook die van diensten, in het bijzonder die van scheepvaart- en kapitaaldiensten. De belangrijke lopende posten van de Nederlandse betalingsbalans zijn daaronder alle te rangschikken.

De vraag naar guldens zal dan worden uitgeoefend om daarmee de uitvoer van ons land te betalen, het aanbod van guldens zal afkomstig zijn van hen die in ons, land hebben ingevoerd. Beide zullen afhangen van de koers van de gulden; geven wij. deze aan met $k$, de waarde van de uitvoer met $U e$, die van de invoer met $U^{i}$, dan zal $k$ in principe worden bepaald door het evenwicht tussen $U^{\prime}(k)$ en $U^{\circ}(k)$, d.w.z. door de vergelijking $U^{4}(k)=U^{\circ}(k)$

waarbij aan de linkerzijde het aanbod, aan de rechterzijde de vraag staat. Wat wij nu wensen te weten, is, hoe bij een verandering van de $k$ de vraag naar en het aanbod van guldens zich zullen wijzigen. Met andere woorden: hoe zal bij b.v. een verlaging van $k$ de waarde van de uitvoer zich wijzigen en hoe de waarde van de invoer? Het is duidelijk dat men ter beantwoording van deze vraag bekend moet zijn met de elasticiteit van de buitenlandse vraag naar Nederlandse goederen en met die van de Nederlandse vraag naar buitenlandse goederen. Omtrent deze elasticiteiten zijn de laatste tijd onderzoekingen ingesteld, die ons althans een globaal inzicht geven ${ }^{\top}$ ).

Men kan de elasticiteit van de uitvoer t.o.v. prijsveranderingen op 1,5 à 2 stellen. Voorts kan men aannemen dat de opbouw van onze exportprijzen ongeveer als volgt is: $1 / 4$ ingevoerde grondstoffen, waarvan de prijzen door de wereldmarkt worden bepaald en $40 \%$ loon, waarvan wij aannemen dat het op den duur met de kosten van levensonderhoud evenredig zal stijgen. Neemt men

7) Voor de uitvoer zie men: J. B. D. Derksen en A. L. G. M. Rombouts, De invloed van het prijsniveau op den uitvoer. De Nederlandsche Conjunctuur, Speciale Onderzoekingen No. 1, Den Haag 1939. 
voor de kosten van levensonderhoud een soortgelijke samenstelling aan, dan laat zich gemakkelijk berekenen dat een koersdaling met $1 \%$ van de gulden, die gelijk staat met een stijging van het wereldprijsniveau, in guldens uitgedrukt, van $1 \%$, tot een stijging van de guldensprijs onzer exportproducten met $2 / 3 \%$ leidt. (Voor de methode van berekening zij naar het aanhangsel verwezen.) In buitenlandse valuta uitgedrukt dalen onze exportprijzen dan met $1 / 3 \%$. De uitgevoerde hoeveelheden zullen dan stijgen met $11 / 2$ à $2 \times$ zoveel, d.i. $1 / 2$ à $2 / 3 \%$. De waarde in guldens uitgedrukt zal tenslotte stijgen met $2 / 3 \%$ meer, dus met 1.2 à $11 / 3 \%$.

Voor scheepvaartontvangsten is de elasticiteit waarschijnlijk vrijwel 1; voor renteontvangsten in guldens is ze 0 , terwijl ze voor dividendontvangsten in vreemde valuta 1 , in NederlandsIndische valuta waarschijnlijk aanzienlijk hoger is. Nadere statistische onderzoekingen zullen, naar ik hoop, hierop licht kunnen werpen.

$\mathrm{Nu}$ komt de vraag, wat er met de invoer gebeuren zal. Men zou in een grove fout vervallen, indien men hiervoor een berekening zou maken gebaseerd op de elasticiteit van deze invoer alleen. Een zodanige berekening toch zou - stilzwijgend gebaseerd zijn op een ceteris-paribus-clausule die hier niet kan aanvaard worden: de clausule nl. dat alleen de prijzen der goederen zouden veranderd zijn en geen andere grootheden. Bij de behandeling van een vraagstuk als het onderhavige, waarbij veranderingen in grote delen van de volkshuishouding te pas komen, is dat ongeoorloofd. De verandering toch die in de uitvoerwaarde optreedt heeft tot gevolg, dat de inkomens stijgen en dientengevolge de consumptieve uitgaven zowel als de investeringen. Voor beide is een verhoogde invoer nodig, evenals voor de vergrote uitvoer op zichzelf. Er treedt dus een - waarschijnlijk aanzienlijke - "shift" op in de invoervraagcurve; een "shift" die het gevolg is van de prijsverandering waarvan wij uitgaan en daarom niet mag worden verwaarloosd. Deze "shift" leidt op zich zelf tot een verhoging van de invoerhoeveelheid. De werking van de prijsverandering, die ten nadele van de buitenlandse prijzen uitvalt, zal dit effect enigszins remmen. Hoeveel, dat hangt af van de elasticiteit, of beter van de substitutie-elasticiteit van buitenlandse (ingevoerde) goederen t.o.v. Nederlandse goederen. Wanneer de ingevoerde goederen moeilijk te vervangen zijn (grond- 
stoffen, eerste voedingsmiddelen), dan zal het substitutie-effect niet groot zijn. Zijn ze gemakkelijk vervangbaar, dan zal dat effect groot zijn.

$\mathrm{Bij}$ de twee genoemde effecten (vermeerdering der hoeveelheden en substitutie) komt echter een derde. De prijzen die voor de import moeten worden betaald zijn, in guldens, hoger. Bij een koersdaling met $1 \%$ is dit reeds een vol procent van de waarde, ongeacht de andere effecten. Er is wegens de genoemde redenen, en in het bijzonder voor een land dat grondstoffen en noodzakelijke voedingsmiddelen invoert, een grote waarschijnlijkheid dat ook de invoer zal toenemen bij een verlaging van de koers van zijn valuta. En gezien het aantal min of meer van elkaar onafhankelijke elasticiteits- en dergelijke coëfficiënten dat hierbij een rol speelt - ook de propensity to consume en de „propensity to invest" hebben op de invoer invloed - is het onder verschillende omstandigheden - men zie weer het aanhangsel - mogelijk dat de vraag- en de aanbodcurve van valuta geheel of bijna parallel verlopen. De kans daartoe is, in het licht der statistische onderzoekingen, zelfs vrij groot.

Dit zou opnieuw betekenen dat een regulering door prijzen, i.c. door koersen, van het evenwicht in de betalingsbalans weinig effect belooft. Een regulering door ,shifts", d.w.z. b.v. door handelspolitieke maatregelen, zou meer effect in uitzicht stellen. Iets waarvan de praktijk zich blijkbaar wel bewust geweest is, de laatste tien jaren.

Ter voorkoming van misverstand zij er op gewezen, dat het bovenstaande geen argumenten bevat tegen een regulering van de bedrijvigheid door middel van wisselkoersen. Slechts een argument tegen het reguleren van het evenwicht in de betalingsbalans.

$\mathrm{Er}$ is nog een verdere conclusie te trekken uit het bijna parallel lopen van de vraag- en aanbodcurve. De mogelijkheid bestaat dan nl. aan de ene kant dat het uiteindelijk evenwicht, na een kleine shift van een der curven, bij een zeer veel lager koersniveau ligt dan voorheen; aan de andere kant, dat het bij een vrij aanzienlijk hoger koersniveau ligt. De instabiliteit der wisselkoersen waarvan wij vooral in de laatste tien jaren getuige zijn geweest - en in buiten-Europese landen reeds aanżienlijk langer - kan daarmee samenhangen. In het bijzonder ook de vaak genoemde mogelijkheid dat "de speculatie zich meester maakt van de koersen" is aanwezig wanneer het ,eigenlijke" evenwicht binnen wijde 
grenzen onbepaald is. Het is nodig er hier aan te herinneren dat wij goudzendingen hebben uitgesloten. Deze veranderen het beeld totaal. Ze vormen $\mathrm{nl}$. een post die op koerswijzigingen uiterst gevoelig, d.w.z. met zeer hoge elasticiteit kan reageren, zolang althans de officiële pariteit gehandhaafd wordt. $Z_{\text {ij }}$ vormen daarom een zeer geschikt middel om, voor korte perioden, de wisselkoers vrijwel exact te fixeren, een fixatie die, zoals ik al zei, verstandig is, wanneer het natuurlijk evenwicht bijna indifferent en de regulerende kracht van de prijs gering is. $\mathrm{Zij}$ mogen echter bij de bepaling van het "natuurlijk" evenwicht geen rol spelen, omdat $z \mathrm{ij}$ nooit blijvend kunnen optreden. Onze beschouwingen hadden betrekking op dit blijvende evenwicht.

Een laatste opmerking moge nog één andere zijde van ons betoog verduidelijken. Indien de aanbodcurve niet alleen - zoals wij reeds aannemelijk hebben gemaakt - een negatieve helling vertoont, maar bovendien als in fig. 1 minder steil verloopt dan de vraagcurve - waartoe de mogelijkheid aanwezig is - zal, bij een vermindering van de exportmogelijkheden het evenwicht van het koersniveau omhoog gaan. Is dit niet een absurde conclusie, die de ongerijmdheid onzer deducties aantoont? Ik meen van niet; het betekent nl. niet, dat de koersen zich ook omhoog zullen gaan bewegen. Zij zullen zeer waarschijnlijk dalen. Zij zullen dan echter nooit - of althans niet spoedig - een evenwichtsstand bereiken. De typische situatie in een labiel evenwicht. Op den duur zal door de werking van de rentestand misschien een einde aan deze beweging komen, doch dat kan een hele tijd duren.

Samenvattend meen ik te mogen vaststellen, dat er enige belangrijke markten resp. complexen van markten zijn, waarop een evenwicht van bijna indifferent of zelfs labiel karakter tot de mogelijkheden behoort. Ik heb hierbij niet op het oog de evenwichten op korte termijn, waaraan Goudriaan vooral aandacht heeft geschonken, doch de evenwichten op wat langere termijn. Het regulerend karakter der prijzen boet op zulke markten aan betekenis aanzienlijk in, en een nadere statistische bestudering er van is dan ook nodig, wil men een juist inzicht verkrijgen in de reguleringsmethoden die, voor elke markt afzonderlijk, de beste zijn. Op deze wijze kan men wellicht komen tot een meer objectief criterium voor de vraag welke markten een regulering van boven wèl en welke ze niet nodig hebben. 


\section{WISKUNDIG AANHANGSEL.}

In dit wiskundig aanhangsel zal de verantwoording gegeven worden voor de hoofdstelling in het voorafgaand betoog door een quantitatieve behandeling van het probleem der loonvorming en dat van de vorming der wisselkoersen. Van beide problemen wordt getracht slechts de allerbelangrijkste hoofdlijnen te geven, een skelet om zo te zeggen, waaromheen zich alle details die men daaraan zou willen toevoegen zouden laten groeperen. Dit skelet wordt slechts gegeven, omdat het het eerste is dat men nodig heeft om in de structuur dezer problemen een inzicht te verkrijgen: een overzicht over het terrein is nodig alvorens men zich met bijzonderheden bezig houdt. En het inzicht wordt niet vergroot, eerder verkleind, wanneer men aanstonds de details in het beeld brengt. Zou men dat n.l. willen doen, dan zou een lastige wiskundige behandeling geheel onvermijdelijk zijn en wel met zoveel variabelen, dat slechts zeer ingewikkelde berekeningen tot de oplossing zouden kunnen voeren. Berekeningen die bij een vroegere gelegenheid door Prof. Goudriaan zijn gequalificeerd als een rit met de nachttrein ${ }^{1}$ ); hij prefereerde de dagtrein, waarbij men ziet langs welke weg men gaat. Getracht is om dit ook hier zichtbaar te maken; maar daartoe is vereenvoudiging onvermijdelijk. Deze vereenvoudiging is ten dele van economische, ten dele van wiskundige aard. De laatste is dat alle grootheden gerekend worden vanaf hun evenwichtsstand; daardoor hebben ze de waarde nul in het evenwichtspunt waarvan uitgegaan wordt. Voorzover verder van kleine afwijkingen van die evenwichtsstand sprake is - en wij beperken ons daartoe - mag men alle functies als lineair beschouwen. De economische vereenvoudigingen zullen in het vervolg ter sprake komen. Door deze vereenvoudigingen is het in het eerste probleem mogelijk om een grafische afbeelding der relaties te geven, die voor sommige beoefenaren der economie aantrekkelijker is en het besef verlevendigt dat men de gang van het betoog doorziet. Zoals al even werd opgemerkt, zijn de problemen en methoden waarover het gaat, op te vatten als een generalisatie van de problemen en methoden van de afzonderlijke markt met zijn vraag- en aanbodlijn tot problemen van enige verbonden het gehele economische leven van een land omvattende markten.

\section{l. Loonvorming in een gesloten land.}

Ter beschrijving van het economisch leven in een gesloten land bezigen wij de volgende categorieën, aangegeven door symbolen die ook bij andere grelegenheden zijn gebruikt:

$u$ omvang van de productie, $p$ prijsniveau, $U$ waarde, $a$ werkgelegenheid, $l$ loonvoet, $L$ loonsom.

Er worden dus twee markten beschouwd, de goederenmarkt en de arbeidsmarkt. Het niet-beschouwen van de kapitaalmarkt vindt zijn oorzaak in diverse omstandigheden, die haar invloed op de uitkomst gering doen zijn, en waaraan reeds meermalen aandacht is besteed ${ }^{2}$ ).

De relaties die tussen deze grootheden bestaan zijn van drieërlei aard.

1) Verslag van de Algemene vergadering van de Vereniging voor de Staathuishoudkunde en de Statistiek, 1936, blz. 68.

2) Vgl. het praeadvies van schrijver dezes voor de Vereniging voor de Staathuishoudkunde en Statistiek in 1936 uitgebracht. Overigens zal in een binnenkort verschijnende studie in de Revue de l'Institut International de Statistique een en ander uitvoeriger besproken worden.

Econ. 1941. 
Ten eerste zijn er relaties die niet anders dan definities zijn. Voor elke markt is de waarde van de omzet gelijk aan het product van prijs en hoeveelheid. Voor kleine afwijkingen kan dit product door een lineaire uitdrukking worden vervangen, die voor de goederenmarkt luidt:

$$
U=\imath p+\bar{p} u
$$

waarbij $\bar{u}$ de evenwicntswaarde van de productie, $\bar{p}$ die van het prijsniveau is. Volkomen analoog heeft men:

$$
L=\bar{a} l+\bar{l} a
$$

Wij kiezen de eenheden waarmee wij werken aldus, dat alle evenwichtsprijzen gelijk zijn aan 1, terwijl bovendien de werkgelegenheid in het evenwicht gelijk is aan 1. Dan vereenvoudigen zich de vergelijkingen (1) en (2) tot:

$$
\begin{aligned}
& U=\tilde{u} p+u \\
& L=t+a
\end{aligned}
$$

Voorts hebben wij voor elk der beide markten een vraag- en een aanbodvergelijking.

De vraagvergelijking voor de arbeid is, naar wij in overeenstemming met de grote lijn aannemen, technisch verbonden aan het aanbod van goederen door een vergeljjking:

$$
a=\alpha u
$$

d.w.z. aangenomen wordt dat een uitbreiding van de productie met een bedrag $u$ een vergroting van de vraag naar arbeid a veroorzaakt die daarmee evenredig is. Dit impliceert, zoals men weet, niet dat de totale vraag naar arbeid evenredig is met de totale productie.

De vraag naar goederen wordt bepaald door wat wij de bestedingsvergelijking zullen noemen. Deze vraag hangt in hoofdzaak af van de inkomens, die gelijk zijn aan $U$ (de waarde der productie) en van het prijsniveau $p$. In vergelijking gebracht:

$$
u=v U-\bar{u} \varepsilon p
$$

waarbij $v$ de propensity to spend en $\varepsilon$ de elasticiteit van de vraag is.

Het aanbod van goederen zal afhangen van de stand der prijzen en van de variabele kosten, welke laatste in hoofdzaak uit loonkosten bestaan. Geeft men de marginale Ioonquote door $\pi_{l}$ en de flexibiliteit der prijzen door $\pi_{u}$ aan, dan is de aanbodvergelijking te schrijven in de vorm:

$$
p=\pi_{1} l+\pi_{13} u
$$

Door gebruikmaking van de vergelijkingen (1). (4) en (5) kunnen wij de vraag naar arbeid uitdrukken als een functie van $l$ alleen, waarin dan verdisconteerd zijn de invloeden van $l$ op de goederenmarkt. Dit leidt cerst tot de vergelijking:

$$
u=v\left\{u+\bar{u}\left(\pi_{1} l+\pi_{n} u\right)\right\}-\varepsilon \bar{u}\left(\pi_{1} l+\pi_{\mathrm{n}} u\right)
$$

De positieve termen corresponderen met de inkomensinvloed, de negatieve met de prijsinvloed op de vraag. Het inkomen zelf is echter weer des te groter, naarmate de productie en het prijsniveau hoger zijn; dit laatste is hoger als de loonvoet hoger is en als de productie hoger is. De productie $t$ wordt dus ten dele door zichzelf, ten dele door het loonniveau bepaald en wel komen positieve zowel als negatieve invloeden voor. Het zal van de grootte der coëfficienten afhangen, welke van deze twee overwegend zal zijn. Lost men de vergelijking $\left(4^{\prime}\right)$ op naar $a$, en gebruikt men dan (3), dan verkrijgt men:

$$
\alpha=\frac{a(v-\varepsilon) \bar{u} \pi_{1}}{1-v-\bar{u}(v-\varepsilon) \pi_{\mathrm{u}}} l
$$

Hieruit blijkt dat het teken van de verandering in vraag naar arbeid 
$a$, die het gevolg is van een loonvoetverandering $l$, verschillend kan zijn al naarmate $v-\varepsilon$ en $1-v$ verschillende waarden hebben. Indien b.v. $v$, de ,propensity to spend", van 1 verschillend is, doch $v=\varepsilon$, dus gelijk aan de elasticiteit van de vraag naar goederen, dan blijkt dat $a=0$, d.w.z. de vraag naar arbeid is van de loonvoet onafhankelijk. De veronderstelling nu dat $v=\varepsilon$ is, is geenszins onrealistisch. $Z$ ij betekent niet anders dan dat een gegeven procentuele verandering in het inkomen, b.v. van $1 \%$, een even grote invloed heeft op de vraag naar goederen als een Even grote procentuele verandering in tegengestelde zin (dus - 1\%) in de prijzen. Dit betekent weer niet anders dan dat de subjecten niet onderhevig zijn aan de "money illusion", m.a.w. slechts reageren op veranderingen in hun reëel inkomen. Een veronderstelling die niet in alle gevallen juist is, maar toch geenszins - vooral voor een evenwicht op iets langere termijn - onrealistisch.

Wij zien dus dat het inderdaad zeer goed kàn voorkomen, dat de vraag naar arbeid door de loonvoet bijna niet wordt beïnvloed. Ten aanzien van

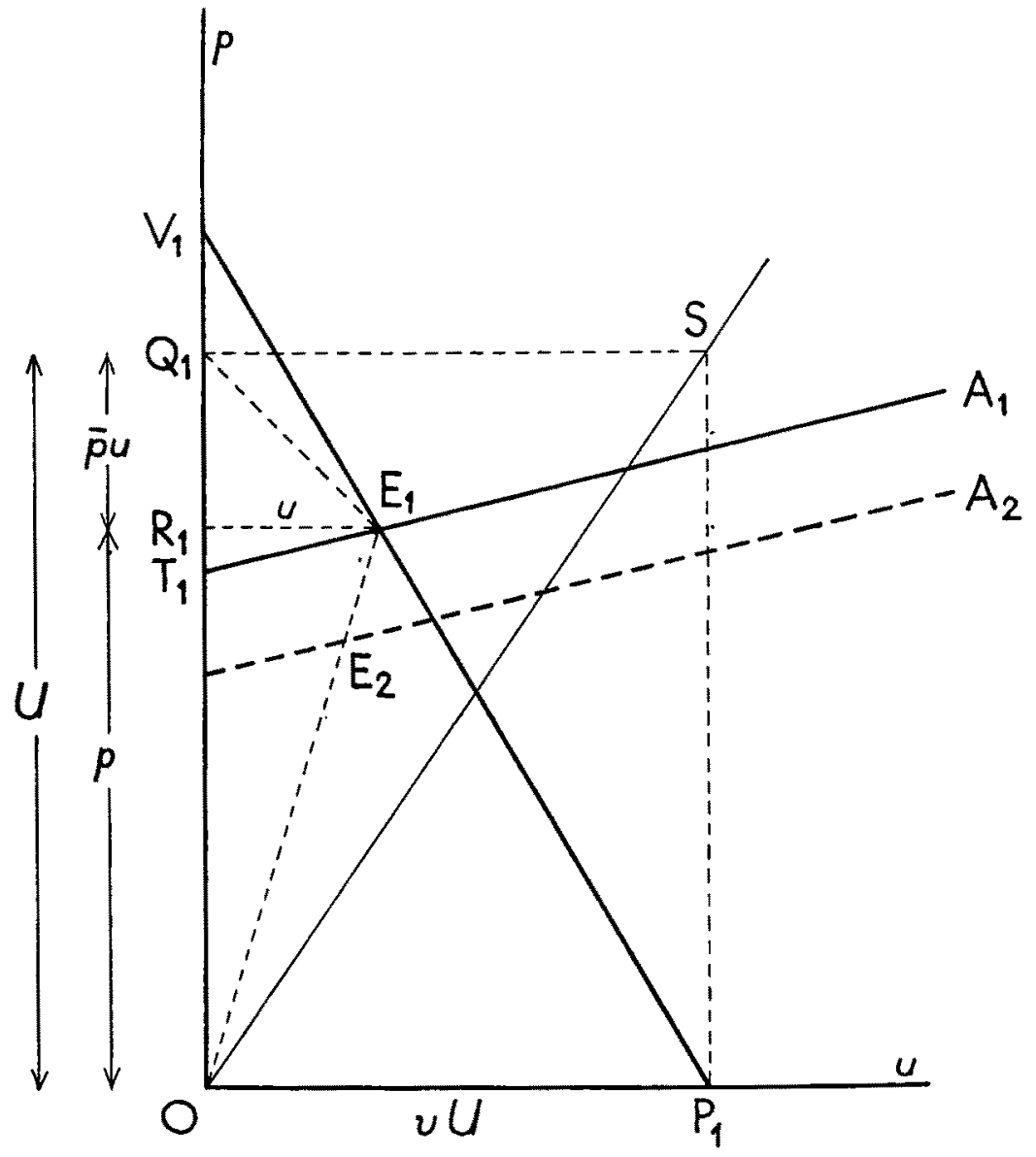

Fig. 3. 
het aanbod is dat onder de omstandigheden van 1920-1940 ook nauwelijks het geval. Er waren zeker steeds een belangrijk aantal werklozen bereid om tegen de heersende loonvoet te werken, indien zij daartoe de gelegenheid kregen. Vraag- en aanbodcurve kunnen dus zeer goed ongeveer parallel verlopen, in welk geval de loonvoet onbruikbaar is als regulateur van dit marktevenwicht.

Het verband tussen de verschillende grootheden laat zich illustreren in een grafische voorstelling, die als een uitbreiding kan worden beschouwd van de vraag- en aanbodanalyse in de gebruikelijke trant. Laat daartoe in figuur 3 de lijn $A_{1}$ de aanbodcurve van goederen, de lijn $V_{1}$ de vraagcurve naar goederen voorstellen. Het marktevenwicht wordt dan als gewoonlijk voorgesteld door de coördinaten van het snijpunt $E_{1}$, waarvan de verticale coördinaat de prijs $p$, de horizontale de omgezette hoeveelheid $u$ voorstelt. In tegenstelling tot de gevallen van een afzonderlijke markt, waarbij de stand van vraag- en aanbodlijn gegeven is, moet er nu tussen de stand dier lijnen (hun shifts, in het bijzonder) en het evenwichtspunt een zeker verband bestaan. Het stuk op de horizontale as dat door de vraaglijn wordt afgesneden $\left(O P_{1}\right)$ moet gelijk zijn aan $v U$, het product van de „propensity tot spend" en het inkomen (d.w.z. de afwijking die het inkomen vertoont van zijn aanvankelijke evenwichtswaarde ${ }^{3}$ )). De $U$ hangt echter af van $u$ en $p$ en kan blijkens onze formule (1) worden gevonden door bij $u$ op te tellen $\bar{u} \times p$. Indien wij nu - waarin wij vrij zijn, indien wij thans niet aannemen dat $\bar{a}=1$ - de eenheden van $u$ zodanig kiezen dat $\bar{u}=1$, dan is dus $U=u+p$.

Door uit $E_{1}$ een lijn $E_{1} Q_{1}$ te trekken onder een hoek van $45^{\circ}$, wordt de afstand $u=R_{1} E_{1}$ overgebracht op $R_{1} Q_{1}$, zodat $O Q_{1}=U$. Wij gebruiken nu hetzelfde assenstelsel tevens om verticaal de $U$ en horizontaal de daarmee corresponderende waarden $v U$ uit te zetten. De punten waarvan telkens de ordinaat $U$ en de abscis $v U$ voorstelt liggen op een rechte lijn $O S$, die de "propensity to spend" tot uitdrukking brengt. De vraaglijn moet nu zodanig lopen, dat de verticale lijn $P_{1} S$ en de horizontale lijn $Q_{1} S$ elkaar op $O S$ snijden.

Ons probleem, de invloed van de loonvoet op de vraag naar arbeid te vinden, bestaat nu in hoofdzaak in het volgende. Blijkens formule (5) is de afstand $O T_{1}$ gelijk aan $x_{1} l$, dus gelijk aan de loonkosten in de prijs (beide gemeten in afwijkingen van de evenwichtsstand). Als de loonvoet zich wijzigt, wijzigt zich deze "shift" in de aanbodlijn. En daarmee verandert dan de gehele grafiek: de vraaglijn incluis. Gevraagd wordt de nieuwe evenwichtsstand $E_{2}$, die aan dezelfde eisen voldoet als $E_{1}$ behalve dat de aanbodlijn $A_{1}$ vervangen is door $A_{2}$. De oplossing wordt het gemakkelijkst verkregen door het punt $S$ het eerst te beschouwen. Dit kan alleen maar langs de lijn $O S$ schuiven. Verkleining van $O S$ in een bepaalde verhouding $m$ heeft voor $O P_{1}$ zowel als voor $O Q_{1}$ alsook voor $O V_{1}$ hetzelfde gevolg. Daar de richting van geen enkele der lijnen zich dus wijzigt, heeft een evenredige verkleining van de gehele figuur plaats. Dit betekent dat alle punten zich in de richting van de oorsprong bewegen; dus ook het evenwichtspunt $E_{1}$. Het nieuwe evenwicht zal dus liggen in het snijpunt van de lijn $O E_{1}$ met de nieuwe aanbodlijn $A_{2}$. Men overtuigt zich ook achteraf gemakkelijk dat dit nieuwe evenwichtspunt $E_{2}$ aan de gestelde eisen voldoet.

3) Deze evenwichtswaarde treedt op wanneer $l=0$, dus wanneer de loonvoet de uitgangswaarde heeft. 
Wanneer zal nu de vraag naar arbeid slechts zeer weinig veranderen bij een gegeven verandering van de loonvoet $l$ ? Klaarblijkelijk wanneer de lijn $O E_{1}$ zeer steil verloopt. Dit zal het geval zijn, wanneer het punt $V_{1}$ zeer dicht bij $Q_{1}$ ligt; en dat is het geval wanneer de elasticiteit van de vraag (de helling van de lijn $V_{1} P_{1}$ ) gelijk aan de "propensity to spend" (de helling van de lijn $O S$ ). Deze voorwaarde hebben wij in het algebraïsch deel onzer beschouwingen ook reeds gevonden. Ik hoop door deze grafiek echter enigszins te hebben bijgedragen tot een analyse "met de dagtrein" van dit omstreden vraagstuk. Tevens echter is wel duidelijk, naar het mij voorkomt, dat de hulp van grafische analyses niet verwacht kan worden voor ingewikkelder problemen. Reeds in dit geval begint de figuur danig onoverzichtelijk te worden; en dit geval is een zeer eenvoudig probleem. Het volgende vraagstuk is, naar mij voorkomt, reeds niet meer met vrucht grafisch op te lossen.

\section{De prijsvorming der wisselkoersen.}

Ter illustratie van het vierde voorbeeld in ons betoog genoemd beschouwen wij thans een land met buitenlands handelsverkeer, zeggen wij Nederland, waarvan wij de toestand beschrijven met behulp van de volgende grootheden:

$1^{\circ}$. Een groep van 9 grootheden, als volgt te rangschikken:

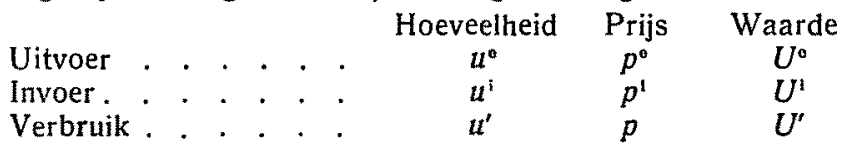

$2^{\circ}$. Daarbij nog drie prijzen: koers van de gulden, uitgedrukt in vreemde valuta: $k$, loonvoet: $l$. Prijsniveau in het buitenland van met Nederlandse producten concurrerende goederen: $p^{\mathrm{w}}$.

Alle prijzen, behalve $k$, zijn in guldens uitgedrukt.

Alle symbolen stellen weer afwijkingen voor van de aanvankelijke evenwichtswaarden, die met een horizontale streep boven het symbool (b.v. $\bar{u}^{\prime}$ ) worden uitgedrukt. Deze evenwichtswaarden zijn voor alle prijsgrootheden gelijk aan 1.

Om de gedachten te bepalen kan worden aangenomen dat het aanvankelijk evenwicht verstoord wordt door het optreden van een autonome verandering in onze uitvoer (een vermeerderde vraag naar onze producten); de vraag worde gesteld hoe de koers van de gulden moet veranderen, opdat er opnieuw evenwicht is.

De gegevens die voor de oplossing van het vraagstuk nodig zijn zullen in de loop van het betoog naar voren komen.

Er zijn weer een aantal typen van vergelijkingen die de economische verschijnselen aan elkaar binden. Wij noemen eerst de in ons vorige vraagstuk niet optredende balansvergelijking die het evenwicht in de betalingsbalans in de nieuwe situatie uitdrukt:

$$
U^{e}=U^{i}
$$

Daarbij is te bedenken dat onder uitvoer ook de uitvoer van diensten begrepen is.

Wij stellen verder vast dat het inkomen van de gezamenlijke Nederlandse subjecten gelijk is aan $U^{\prime}$; het is n.l. gelijk aan de waarde der productie $U^{\prime}+U^{\mathrm{e}}$, verminderd met de (buitenslands gemaakte) kosten $U^{\prime}$. (De gehele invoer wordt als kosten beschouwd, omdat in de waarde der productie ook medegerekend wordt de waarde van goederen die in het binnenland 
alleen het kleinhandelsstadium of het stadium van montage doorlopen). Doordat $U^{*}=U^{\prime}$ is het inkomen dus $U^{\prime}$.

Als tweede soort vergeliikingen hebben wij wederom de definitievergelijkingen. Deze zijn van hetzelfde karakter als in het vorige vraagstuk en kunnen daarom zonder nadere toelichting worden neergeschreven:

$$
\begin{aligned}
& U^{e}=\bar{u}^{\circ} p^{\mathrm{e}}+u^{\mathrm{e}} \\
& U^{\prime}=\bar{u}^{\mathrm{l}} p^{\mathrm{i}}+u^{\mathrm{l}} \\
& U^{\prime}=\bar{u}^{\prime} p+u^{\prime}
\end{aligned}
$$

De derde soort vergelijkingen zijn de vraagvergelijkingen. De vraag naar exportproducten zal afhangen van het verschil tussen 4) hun prijzen en de prijzen der concurrerende artikelen, mits uitgedrukt in eenzelfde valuta en voorts van de conjunctuur in het buitenland. Wij kunnen dit weergeven door de formule

$$
u^{\mathrm{e}}=u_{\mathrm{o}}{ }^{\circ}-\bar{u}^{\mathrm{e}} \varepsilon^{\circ}\left(p^{\mathrm{e}}-p^{\mathrm{w}}\right)
$$

waarbij $\varepsilon^{\circ}$ de substitutie-elasticiteit voorstelt van onze uitvoerproducten en $u_{\mathrm{w}}{ }^{*}$ de invloed van de buitenlandse conjunctuur; $u_{\mathrm{o}}{ }^{\mathrm{e}}$ stelt de autonome shift in de vraag voor, waarvan wij zijn uitgegaan bij de evenwichtsverstoring.

De vraag naar invoergoederen zal op soortgelijke wijze afhangen van liet prijsverschil van de geïmporteerde en de Nederlandse prijzen, en voorts van de omvang van de productie in Nederland, die als de belichaming van de vraag naar producten in het algemeen kan worden beschouwd. Dit kan als volgt worden weergegeven:

$$
u^{1}=v^{1}\left(u^{\circ}+u^{\prime}\right)-\bar{u}^{1} \varepsilon^{l}\left(p^{1}-p\right)
$$

Daarbij kan $v^{\prime}$ de importquote worden genoemd, terwiil $\varepsilon^{\prime}$ de substitutieelasticiteit van de invoer t.o.v. binnenlandse productie is.

Tenslotte is er een vraagfunctie voor het binnenland. Deze vraag naar goederen en diensten zal afhangen van het inkomen en van het prijsniveau:

$$
u^{\prime}=v^{\prime} U^{\prime}-\bar{u}^{\prime} \varepsilon^{\prime} p
$$

waarbij $U^{\prime}$, zoals gezegd, het inkomen voorstelt, $v^{\prime}$ de marginale ,propensity to spend" en $\varepsilon^{\prime}$ de elasticiteit van de vraag.

De vierde groep van vergelijkingen wordt gevormd door de aanbodvergelijkingen. Wij willen deze opvatten in de zin van Marshall, n.l. dat zij de prijs aangeven, waartegen men bereid is aan te bieden.

Tell aanzien van de loonvoet nemen wij aan dat deze slechts afhangt van de kosten van levensonderhoud $p$ :

$$
l=\lambda_{1} p
$$

Het ontbreken van een term die met de werkgelegenheid samenhangt betekent dat het aanbod als volkomen elastisch wordt beschouwd. Voor tijden van een uitgesproken werkloosheid is dit realistisch te achten.

Ten aanzien van de kosten van levensonderhoud $p$ nemen wij aan dat deze afhangen van de loonvoet en van de prijs van ingevoerde goederen:

$$
p=\pi_{1} p^{i}+\pi_{2} l
$$

waarbij $\pi_{1}$ de importquote en $\pi_{2}$ de loonquote in de waarde der productie voor binnenlands verbruik is. Het ontbreken van een term met $u^{\prime}+u^{\circ}$, de nmvang der productie, betekent dat het aanbod als volkomen elastisch wordt beschouwd. Blijkens recente statistische onderzoekingen is deze veronderstelling een goede benadering der feiten ${ }^{5}$ ).

4) Zoals reeds werd opgemerkt is dit verschil in eerste benadering gelijk an de verhouding, door de bijzondere keuze der eenheden.

5) Vgl. J. Tinbergen en A. L. G. M. Rombouts, De samenhang tusschen de prijzen van ingevoerde grondstoffen en die van afgewerkte producten in Nederland, De Nederlandsche Conjunctuur, X (1939), blz. 150. 
Eenvoudigheidshalve wordt dezelfde veronderstelling gemaakt t.a.v. exportgoederen, zodat ook daarvoor de vergelijking geldt:

$$
p^{\circ}=\pi_{1} p^{1}+\pi_{2} l
$$

De importprijzen zijn gegeven door de wereldmarkt, die wij als onafhankelijk van de economische toestand van Nederland beschouwen. M.a.w., de prijzen uitgedrukt in vreemde valuta zijn constant en bij onze wijze van meten dus gelijk aan 0. Wanneer nu echter, zoals in ons probleem als mogelijkheid wordt geïntroduceerd, de koers van de gulden een afwijking $k$ ggat vertoonen van zijn evenwichtsstand van voorheen, dan zullen de importprijzen in guldens met grote benadering gelijk worden aan $-k$; wij hebben dus:

$$
p^{1}=-k
$$

Hetzelfde geldt voor: $p^{w}=-k$

Daarmee zijn nu 12 vergelijkingen gevonden die de bepaling van de 12 variabelen toelaten die als onbekenden zijn geïntroduceerd. Als bekende grootheden treden daarbij op alle door Grieksche letters aangeduide symbolen, alle met een horizontale streep voorziene evenwichtswaarden van voorheen ell de grootheid $u_{0}{ }^{\mathrm{e}}$, de autonome component in de uitvoer.

$\mathrm{Er}$ is aanleiding om in de notatie van sommige dezer data nog wat meer uniformiteit te brengen. De invoerquote is n.l. reeds tweemaal ingevoerd, n.l. als $v^{\prime}$ en als $\pi_{1}$; kiezen wij $\pi$ als definitief symbool. Wij kunnen dan tevens $\bar{u}^{1}$ vervangen door $\pi\left(\bar{u}^{\prime}+\bar{u}^{\mathrm{e}}\right)$, terwijl bovendien $\bar{u}^{\mathrm{l}}=\bar{u}^{\mathrm{c}}$.

Het invoeren van de importquote als een grootheid die eventueel nog gevariëerd kan worden heeft het voordeel, dat dan nog kan worden nagegaan in hoeverre onze conclusies afhankelijk zijn van deze structuurgrootheid. Wanneer wij dat doen, verdient het echter aanbeveling om de loonquote $\pi_{2}$ van deze invoerquote afhankelijk te stellen. Hoe groter de laatste, des te minder blijft er van de prijs over voor beloning der binnenlandse productiefactoren. Daar in de meeste landen rond de helft van het nationale inkomen arbeidsinkomen is, begaan wij geen grote fout indien wij stellen dat

$$
\pi_{2}=0.5(1-\pi)
$$

Het is niet de bedoeling om in dit aanhangsel op alle details van de oplossing en op mogelijke alternatieven in te gaan. Dit zal in een weldra elders verschijnend artikel worden ondernomen ${ }^{6}$ ). Wij vermelden nu slechts de oplossing. Deze luidt:

$$
k=\frac{u_{\mathrm{o}}{ }^{\mathrm{e}}}{\pi^{\mathrm{e}}} \frac{1+\pi}{-1+(1-\pi) \varepsilon^{\mathrm{e}}+\varepsilon^{1}+\frac{2 \pi\left(\varepsilon^{\prime}-v^{\prime}\right)}{1-v^{\prime}}}
$$

De koerswijziging die nodig is om bij een gegeven wijziging in de vraag naar onze exportgoederen het evenwicht in de betalingsbalans te herstellen blijkt dus evenredig te zijn met de verhouding van deze vraagwijziging tot de voormalige export en voorts af te hangen van de drie elasticiteiten $\varepsilon^{\mathrm{e}}, \varepsilon^{\prime}$ en $\varepsilon^{\prime}$, van de importquote $\pi$ en van de ,propensity to spend" $v^{\prime}$. De invloed van deze laatste verdwijnt, wanneer weer zou worden aangenomen - men zie het vorige vraagstuk - dat er geen "money illusion" heerst. Dan toch is $\varepsilon^{\prime}=v^{\prime}$ en valt de laatste term in de noemer weg.

Er zijn nu zeker waarden te vinden voor $\pi, \varepsilon^{0}$ en $\varepsilon^{1}$ die er toe leiden dat de tweede factor in het rechterlid van (13) een groot getal wordt.

6) Zie noot 2) van dit Aanhangsel. 
Daartoe behoeft de noemer slechts een klein getal te zijn, dus

$$
N=-1+(1-\pi) \varepsilon^{c}+\varepsilon^{i} \approx 0
$$

In dergelijke gevallen is de koers een slecht regulator. Statistische metingen omtrent de beide elasticiteiten zijn nog slechts op beperkte schaal beschikbaar. Voor Nederland is de voorlopige indruk dat $\varepsilon^{2}$ op $0.6, \varepsilon^{e}$ op 1.5 à 2 kan gesteld worden. Daar de invoerquote gelijk aan 0.25 kan worden aangenomen, is de uitdrukking $N$ nog tamelijk sterk positief voor ons land, n.l. $N=-1+(1.1$ à 1.5$)+0.6=0.7$ à 1.1 . Er zijn echter vrij zeker landen, waarvoor deze elasticiteiten geringer zijn. Pogingen om voor Engeland in de periode 1870-1914 metingen van deze elasticiteiten te ondernemen, leidden tot waarden van de orde van grootte van $1 / 4$ voor beide. Inderdaad is an te nemen dat voor een relatief groot land de $\varepsilon^{\circ}$ aanzienlijk geringer is dan voor een relatief klein land, terwijl een land dat noodzakelijke voedingsmiddelen en grondstoffen invoert de $\varepsilon^{i}$ klein zal zijn. Voor de genoemde waarden van deze elasticiteitscoëfficienten zou reeds een negatieve waarde van $N$ zijn verkregen, hetgeen de mogelijkheid van waarden in de buurt van nul demonstreert. Onze beschouwingen hangen dus niet in de lucht. 